\title{
Ending AIDS - A Generational and Program Informed Approach
}

\author{
Wole Ameyan* \\ Medical Coordinator, Solidarité Thérapeutique et Initiatives pour la Santé (SOLTHIS), Sierra Leone
}

Submission: January 06, 2018; Published: March 15, 2018

*Corresponding author: Wole Ameyan, Medical Coordinator, Solidarité Thérapeutique et Initiatives pour la Santé (SOLTHIS), Freetown, Sierra Leone, Tel: +23276704933; +447425802519; Email: wole.ameyan@solthis.org; woleameyanjr@yahoo.com

\section{Opinion}

Since the discovery of HIV, many initiatives and processes have gone into mitigating the effects of the disease on communities and populations to great success. Indeed, the status of the HIV epidemic today is a strong testament to what the human race can achieve so long as we put our minds to it, work hard and collaborate. From being a dreaded disease, leaving no hope to those who contract it, HIV has now become only a chronic condition, very manageable with potent treatments with people living with HIV able to live long, healthy, fulfilling and productive lives. However, there still remain huge challenges to finally solving what is still largely ravaging many communities. A key challenge for country HIV programs is that of strategic planning, implementation and follow up. Inadequate technical support, poor research and data management capacity, limited organizational coordination and knowledge management are some of the main constraints impeding proper strategic direction for many HIV country programs.

Long term strategic planning and program informed decision making is key to ensuring that progress made already in the AIDS response is accelerated at a momentum needed to achieve global targets as it relates to the sustainable development goals. Ending AIDS is possible but through key strategic thinking and planning. A strategic way to end AIDS is through a generational approach that keys into and gives priority to current initiatives towards achieving an AIDS free generation. Strategic programming towards an AIDS free generation should focus on three key strategic areas: prevention of mother to child transmission of HIV (PMTCT); early infant diagnosis of HIV and prevention, care and treatment of HIV in childhood and adolescence. However, there remain key obstacles to tackling these key areas. Prevention of mother to child transmission of HIV remains a key strategic intervention towards ending AIDS. Key to achieving this is the four prongs of PMTCT. Ensuring that women of reproductive age who are HIV negative remain so through targeted sensitization on HIV prevention, intermittent HIV testing and counseling and a context informed condom programming is key. Uptake of family planning services is crucial to PMTCT.

Unfortunately, uptake of family planning services remains low in many settings. Barriers to the uptake of family planning services need to be deciphered to inform interventions to improve this very important service. HIV positive pregnant and breastfeeding women require intensified support that emphasizes retention in care, adherence to treatment with the aim of achieving viral suppression during pregnancy but very crucially during labour, parturition and breastfeeding. Infant prophylaxis in line with global best practices need to be scaled up while services for early infant diagnosis, which currently are below the required levels in scale and quality, need to be focused on and intensified.

Early infant diagnosis still faces constraints of enormous proportions in many countries. Country programs need to unpack and deal with the main barriers of human, infrastructural, informational, material and organizational dimensions inhibiting the proper functioning of EID services. Childhood and adolescent HIV programming needs to be at the forefront of a program informed and generational approach towards ensuring that AIDS is ended in the not too distant future. One-seventh of new HIV infections occur during adolescence and over $30 \%$ of all new HIV infections globally are estimated to occur among youth ages 15 to 25 years. The need to focus on the provision of quality comprehensive services for children and during the adolescent period cannot be over emphasized. This article therefore unequivocally calls for a generational approach that focuses on adolescent service delivery to support access to quality services for this age group who are being left behind and for whom HIV services are vitally important. Differentiated care with a focus on adolescent centered care will be critical in achieving global goals on adolescent HIV service provision while strategies towards integration with broader SRH and adolescent friendly services is essential. Finally, stakeholder and strategic partnerships 
between high performing and low performing country HIV programs and strategic guidance and support from leading global institutions like the world health organization needs to be looked into with a view to ensuring that country and donor needs are aligned and met. Such strategic partnerships should form the fulcrum of efforts for program informed, generational approaches toward sending AIDS.

\section{Disclaimer}

The views expressed in this article are the author's alone and should not be attributed to Solthis or any other institution with which he is associated.

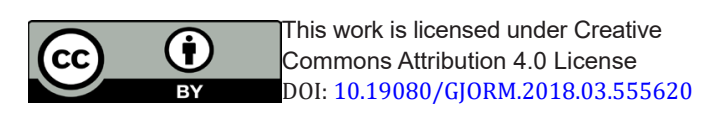

\section{Author Information}

Dr. Wole Ameyan, MIPH is a medical doctor and HIV specialist with 9 years of technical and strategic HIV program management experience

\section{Your next submission with Juniper Publishers will reach you the below assets}

- Quality Editorial service

- Swift Peer Review

- Reprints availability

- E-prints Service

- Manuscript Podcast for convenient understanding

- Global attainment for your research

- Manuscript accessibility in different formats ( Pdf, E-pub, Full Text, Audio)

- Unceasing customer service

Track the below URL for one-step submission https://juniperpublishers.com/online-submission.php 